\title{
The moving frontier and beyond: the third sector and social policy
}

\author{
Chapter submission for Social Policy Review
}

SHORTENED Draft, 27-08-18

REVISED Draft, 15-10-18

Dr Rob Macmillan

Centre for Regional Economic and Social Research

Sheffield Hallam University

rob.macmillan@shu.ac.uk

\author{
Dr Jeremy Kendall \\ School of Social Policy, Sociology and Social Research \\ University of Kent \\ J.Kendall@kent.ac.uk
}

\section{Introduction}

Asked to identify the most influential books and articles in Social Policy, the lists of many social policy scholars would probably include Esping-Andersen's The Three Worlds of Welfare Capitalism (1990). The elaboration of three ideal typical 'welfare regimes' (liberal, conservative-corporatist and social democratic) has transformed the way we think about social policy and welfare states (Powell, 2016: 660). Yet its theoretical architecture is built upon a curious omission. Remarkably it says very little about the role of the third sector in social policy and welfare provision. 'The Three Worlds of Welfare Capitalism' has no indexed references at all to the third sector or allied terms. The follow up study Social Foundations of Postindustrial Economies (Esping-Andersen, 1999) is bereft of such concepts, with one exception. Here a welfare regime is defined as: '... the combined, interdependent way in which welfare is produced and allocated between state, market, and family' (ibid: 35-6). The accompanying footnote (n.2, p.35) advises: 'To this triad we should rightfully add the 'third sector' or voluntary, or non-profit, welfare delivery. In some countries, the voluntary sector (often run by the Church) does play a meaningful, even significant, role in the administration and delivery of services'. It is noted that cross-national comparison of the third sector is rare, but Salamon and Anheier (1998)'s analysis is cited. And that's it. On this basis, it would seem that the third sector in social policy is relegated to a footnote.

Further, Richard Titmuss is rightly regarded as one of the intellectual forces behind the development and expansion of social policy. He writes powerfully about altruism in The Gift Relationship (1970), but overall he says very little about charitable or voluntary action. Reisman notes a comment made by Titmuss in a letter to a colleague in 1959: 'The modern state needs, in addition to collective public services, a variety and diffusion of genuine voluntary agencies' (Reisman, 2001: 64). But that's pretty much it. Titmuss 'admired voluntarism but had a preference for the State' (ibid, 66). 
Contemporary writing in mainstream Social Policy appears only slightly less prone to this general neglect. For example, Beresford's magisterial All Our Welfare contains only a brief and familiar critical description of charity as paternalist and stigmatising, in the context of disabled people's movements (Beresford, 2016). An edited collection of writings on aspects of The Coalition Government and Social Policy (Bochel and Powell, 2016) has remarkably little reflection on the role of the third sector, and little consideration of relevant policy developments of the time, such as 'the Big Society'. Pete Alcock's Why we need welfare: Collective action for the common good perhaps stands out as the exception which proves the rule (Alcock, 2016). Alcock highlights the important role played by non-state actors in the historical provision of welfare, notes that the mixed economy of welfare has and always will be with us, and discusses how its character has changed as societies' needs have evolved.

So, it is reasonable to claim that Social Policy as a whole has tended to underplay the significance of the third sector. We take this argument as the point of departure for this chapter. In the discussion which follows, we consider the possibility that the third sector has been marginalised in social policy in part because of entrenched assumptions about 'sectors', in which the state, and latterly the market, are privileged in social policy thinking. As well as ignoring the 'loose and baggy monster' heterogeneity of organisational forms and approaches (Kendall and Knapp, 1995), and the complex intertwined array of hybrid relationships across sectors, the 'third sector' itself becomes typically defined as a residual (non-bureaucratic, non-profit) category, understood only in terms of its broad relationship to the state and the market. The sector is seen as occupying a space on 'the other side' of a 'moving frontier' with the state (Beveridge, 1949; Finlayson, 1994). We suggest that third sector scholarship has been implicated in reinforcing some of these assumptions, in its efforts to identify and define a distinctive and valuable realm of activities for enquiry in social policy.

To pursue this line of argument, we first review and assess, in the next section, the relevance of earlier attempts to promote and prioritise voluntary and community action. The chapter then considers how we might move beyond these perennial debates to develop a more nuanced account of third sector contributions to social policy. The aim here is to challenge the notion of a single 'moving frontier' between state and third sector. In outlining a preliminary map of new thinking in the contemporary political and economic context, we suggest some promising conceptual directions at two levels. A key reference point is the notion that meso-level field dynamics are crucial in shaping institutional relationships, wherein boundaries evolve differently in distinctive areas of policy (so that the 'frontier' in social care can and should be differentiated from the 'frontier' in health care, or social housing, for example). Another is the reconceptualisation of the macro environment, as a domain for isomorphic pressures, ideologies and governmentalities. These phenomena shape the third sector in complex ways, and may even threaten sectoral identities, although drawing on more recent new institutionalist formulations and analysis of 'hybridization', we will see that the associated processes can be fluid, co-evolve with other sectors, and should not be understood in a narrowly deterministic way.

\section{Beyond the state - the welfare mix}


Following the lead set by Titmuss, post-war social policy often sought to examine and explain the policy objectives, principles of administrative arrangement and the distributional outcomes for citizens of the new welfare state. And in doing so it was explicitly critical, albeit within a narrow frame of reference: seeking to discover and repair any gaps in the safety net, to explore unmet needs and to extend welfare rights and provisions. Yet the assumptions of state-led and provided welfare services remained. There were some critical voices against this grain within the field itself. Robert Pinker's sophisticated pluralism is perhaps the key example. A multiple array of services organised within and across sectors would, he suggested, mitigate the risk of dependency associated with any one form of provision (Pinker, 1979). But otherwise, for the three post war decades, the State remained the primary focus for most scholars.

From the mid-1970s onwards, however, greater space was being given to more critical approaches, from a range of ideological standpoints, to the role of the state in welfare. In various ways these became part of a resurgence of interest in the role of voluntary action in what increasingly became referred to as the 'welfare mix'. We consider three developments here: welfare pluralism, associative democracy and social capital.

Welfare pluralism - related to, but seeking to move beyond Pinker's accounts - came to prominence in the late 1970s and early 1980s, as one kind of social policy response to a wider set of economic, political and ideological crises undermining the Keynesian-social democratic welfare state. Indeed, from the standpoint of 1983, it was suggested that welfare pluralist ideas, alongside privatisation, were the most important and influential in welfare at the time (Beresford and Croft, 1983: 21). Explorations of fiscal and legitimation crises on the left (O'Connor, 1973; Gough, 1979) accompanied critical concerns with political 'overload' and 'ungovernability' on the right (King, 1975; Birch, 1984), but under a common assumption that capitalism and the welfare state had become locked in an unholy alliance (cf. Offe, 1984).

The right's resurgence in the 1980s led to the first sustained attempts at welfare state retrenchment, based on the idea that market and individualist forms of welfare provision were always preferable to the failures of collective state provision. At the same time, welfare pluralists were accepting a notion of 'state failure', but envisaged instead a nonstate version of collective welfare provision, in which the voluntary sector would play an enhanced 'radical' role (Gladstone, 1979; Hadley and Hatch, 1981). This was a more ambitious account of non-state welfare provision than that offered by the earlier Wolfenden Committee on the Future of Voluntary Organisations (Wolfenden, 1978), which seemed to offer some recognition of the different roles of voluntary organisations, but little more than a modest suite of proposals for supporting these. Hadley and Hatch's Social Welfare and the Failure of the State ruffled a lot of social policy feathers when it was published in 1981, in part because it seemed to accept half of the New Right's critique of a bureaucratic welfare state, and was thus thought to have offered revisionist succour to an attack on social democratic principles, just at the point at which they were most in need of a sturdy defence (Beresford and Croft, 1983). It was heavily criticised for making naïve assumptions about the power and potential of voluntary action, and overlooking problems 
such as inconsistency, patchiness, duplication and lack of accountability to users (ibid: 22; see also Brenton, 1985; Johnson, 1987).

Arguably, however, the debate in social policy quickly moved on and welfare pluralism was eclipsed by largely defensive efforts amongst analysts to chart the consequences of market and quasi-market inspired welfare restructuring in the mid to late 1980s and early 1990s (Le Grand and Bartlett, 1993), and by efforts to open up new dimensions of social policy analysis, particularly around gender and race (Williams, 1989). Some researchers tried to keep alive a critical and perhaps less evangelical analysis of the mixed economy of welfare, by looking at the contemporary "crisis" (Johnson, 1987) or drawing attention to previously underplayed historical third sector roles (Finlayson, 1994; Prochaska, 1988).Overall the welfare pluralist project faltered into the early 1990s, even if a semblance of a pluralist welfare system, in the sense of multiple providers and approaches, began to emerge in practice (Deakin, 1987: 177).

However, thinking about welfare beyond the state gained a further boost from outside the social policy mainstream, in two significant interventions from political scientists, promoting the notions, respectively, of 'associative welfare' and 'social capital.' The late Paul Hirst's Associative Democracy was published in 1994 as a work of normative political theory focusing on an enhanced role for associations in governance and welfare. Drawing on a legacy from Harold Laski and G.D.H. Cole, Hirst's aim was simultaneously to renew representative democracy and overcome the problems of centralised state bureaucracy. The central claim was 'that individual liberty and human welfare are both best served when as many of the affairs of society as possible are managed by voluntary and democratically self-governing associations' (Hirst, 1994: 19). Hirst followed familiar pluralist themes in arguments around welfare provision, by criticising large scale hierarchical systems as obstacles to participation. A multiplicity of self-governing associations would instead offer a means both for the expression and pursuit of different ways of meeting needs, and provide both voice and choice for citizens. In Hirst's vision, the state's role changes fundamentally, freed from the over-extended burden of providing services to fulfil a public oversight and regulatory role, ensuring appropriate governance of associations, whilst funding many of them to ensure universal services of guaranteed quality.

Hirst's associational model was a more visionary and ambitious version of welfare pluralism. It draws strength from the same welfare pluralist lines of argument, for example doubts about the capacity, and quality of centralised state provision, but it has a stronger theoretical and normative underpinning. In some ways it responds to a recognised weakness in welfare pluralism; that a radical new approach to welfare services was being promoted on only the basis of existing, small scale empirical examples of neighbourhood and self-help initiatives (Beresford and Croft, 1983: 22-23). In contrast, Hirst proposes nothing less than a complete overhaul of economic and social arrangements, albeit established rather gradually and organically. Subsequently commentators have sought to apply the framework to existing institutional arrangements, and to explore its political and emancipatory value. It has been recognised as possessing some real potential, but in practice highly constrained in terms of its ability to ensure heightened democratic accountability (in particular, see Smith 2011). 
Perhaps a more fundamental criticism of the whole associational project would focus on the challenge of pursuing pluralism organically in a society marked by significant inequalities of power, status and resources - whether this can really be overcome by the healing powers of non-state networks of association' (Amin, 1996: 309). Formal rights to join and leave such associations may, in the absence of firm state regulation, coordination and intervention end up mirroring or even amplifying wider social divisions (see Jordan, 1996).

Associationalism was also at the heart of Robert Putnam's empirical studies of 'social capital' in Italy and the United States (Putnam et al, 1993; Putnam, 2000). Echoing de Tocqueville's Democracy in America, Putnam's project highlights the importance of nonstate civic associational networks, for example in sports clubs and cultural societies, for generating trust, pro-social norms and co-operation. Social capital is defined as those features of social organisation, such as trust, norms and networks that can improve the efficiency of society by facilitating coordinated actions' (Putnam et al, 1993: 167). In later work (Putnam, 2000), different types of social capital were articulated: 'bridging' social capital involves network ties amongst people with different socio-economic characteristics, 'bonding' social capital refers to the links between people with similar characteristics, and 'linking' social capital attends to the connections between people with more and less power, influence and authority.

During the late 1990s and through the 2000s, social capital became a highly influential concept for academics and for policy-makers, achieving political resonance with the communitarian strand of New Labour's "third way" narrative (Taylor, 2000; Johnston and Percy-Smith, 2003; Kendall, 2003; Halpern, 2005; Field, 2017). But just as the extent of attention to social capital grew, so did the level and range of criticism. Doubts were expressed about whether the argument could be generalised across different political and institutional contexts (Hall, 1999). Further, Putnam's social capital tended to be viewed as a relatively benign and productive resource, focusing on trust, reciprocity and co-operation. As such it downplays or neglects issues of power. Other, more realistic and sociologically nuanced conceptualisations of social capital were deployed in contesting these debates, emphasising the unevenly distributed power of networks and connections and their use in every day struggles for other forms of capital, such as material resources and symbolic status (Grenfell, 2012).

For the argument pursued in this chapter, however, the main concern relates to the framework's pluralist foundations. Putnam's social capital is resolutely society-focused; indicative, perhaps, of its American origins, ambivalent about the state as potentially 'crowding out' civic action (Hall, 1999; Szreter, 2002). Yet, these arguments have come under significant challenge, especially outside the US, with both quantitative research (for example, see van Oorschot and Arts (2005) and with local qualitative work. Regarding the latter, Maloney et al (2000) provide an example of a UK study emphasising the dense interpenetration of state and civil society in ways which have a direct bearing on the latter's role in generating and sustaining social capital.

\section{Getting to grips with the third sector - a growing research field}


Research relating to the third sector and its social policy contributions has not been limited to those informed by the particular theoretical lenses discussed so far: a more general field of knowledge was also evolving, gaining momentum from the 1980s onwards. At this time the UK voluntary sector research agenda focused on five broad questions (Halfpenny and Reid, 2002): (1) what organisations comprise the sector? (2) how is the sector resourced? (3) why do voluntary organisations exist? (4) how do voluntary organisations differ from other organisations? and (5) what is the voluntary sector's relationship with other sectors? Arguably most attention has been paid to the first, second and fourth of these themes, although the fifth grew as a concern during the closer 'partnership' relationship between the voluntary sector and the state under the 1997-2010 Labour governments (Lewis, 2005).

Questions of organisational composition and resources have been the focus of conceptual and definitional work, linked to efforts to map and measure the scale and scope of the voluntary sector. In the mid-1990s, the UK was part of the Johns Hopkins Comparative Nonprofit Sector project, a major cross-national research effort to quantify and compare the scale and scope of the voluntary sector and civil society across the world, which was then renewed and extended in later work (Kendall and Knapp, 1996; Kendall, 2003). Using a 'structural-operational definition' this was not only the first significant attempt to outline and measure the scope of the sector, but also provided the empirical foundations of the 'social origins of civil society' model, a welfare regime-related theory which suggests the existence of a small range of distinct civil society regimes (Salamon and Anheier, 1998; Salamon et al, 2017). This theory argues that the voluntary sector is deeply embedded in specific and enduring national welfare contexts, and its size and role is, fundamentally, the product of the balance power between social groups over time. Drawing on historical as well as contemporary materials, Salamon and Anheier (1998: 241, based on Kendall and Knapp (1996)), characterised the UK as expressing a liberal regime, while also embodying some significant social democratic features.

More generally, efforts to understand the scale, organisational composition and resources of the sector have traditionally been hampered by limitations in the scope and quality of data (Tarling, 2000). Yet, the situation has improved over the past two decades, and from work building on the Johns Hopkins study, we have gained a better and more consistent picture of the voluntary sector in the UK over time, even if the applied definition has tended to be narrower than many would like, focussing primarily on 'general charities', a subcategory of all charitable bodies (itself a subset of what Kendall and Knapp referred to as the 'broad' voluntary sector). For example, we have learnt of its aggregate income growth since the early 2000s, albeit with a more turbulent pattern during the Coalition government; and of how 'earned income' has become more important over this time scale. Conversely, aggregate income from government grew strongly under New Labour, but has faltered under Coalition and Conservative administrations, initially against the backdrop of a 'Big Society' ideology correlating politically with the hostility towards statutory support.

More recently we have learnt a great deal more about the differentiated experience between the largest voluntary organisations (e.g. those typically with annual incomes of f1m and above) and other, small and medium sized agencies. The former amount to only $3 \%$ of charities, but the bulk of the economic weight of the sector, together representing $80 \%$ of the sector's aggregate annual income, and they have been faring better financially in 
recent years. Indeed income growth in the last couple of years has been confined to the largest organisations (Crees et al, 2016; Bernard et al, 2017), adding grist to the mill of those who tend not see a single voluntary or third 'sector' as a coherent definitional category, policy object or political project, but rather a fracturing space of different interests and fortunes (Macmillan, 2013; Rochester, 2013).

Allied work using national survey data and carefully constructed large-scale data sets of charity accounts over time has also enabled a clearer picture to emerge comparing and contrasting a range of different geographical situations, with more details on different sources of income over time in different domains, and analyses conducted on how these situations relate to the climate of austerity prevailing in the aftermath of the economic crisis (Clifford et al, 2013; Clifford and Mohan, 2016; Clifford, 2017; Kendall et al, 2018). These findings are suggestive of diverse experiences and divergent fortunes across the third sector, challenging the idea of a single coherent sector, and implying feasibility limits to any aspirations to achieve 'strategic unity' in relation to the public policy agenda (Alcock, 2010).

A further theme - how voluntary organisations are different to other kinds of organisation has arguably been more fundamental in defining this area as a field of study. Researchers have been interested in identifying, exploring and responding to the distinctive features, practices, contributions and challenges of running voluntary organisations (Billis and Harris, 1996). Traditional organisation and management theory, derived primarily from work with private firms is somewhat ill-suited, it is said, to the special characteristics of voluntary organisations and the values and motivations of those involved in them. Theoretically, sources of distinctiveness might involve the trustworthiness which arises from the fact that voluntary organisations are not, on the face of it, in it for the money - they do not distribute surpluses or profits to shareholders (Hansmann, 1980), or from the comparative advantage derived from 'stakeholder ambiguity', where a complex combination of multiple stakeholders are involved in the governance and management of organisations (Billis and Glennerster, 1998). In practice, claims for distinctiveness tend to make reference to, amongst other factors, organisations' closeness to marginalised communities of interest and place (Billis, 2001), their independence from government and commercial interests (Baring Foundation, 2012), and the use and combination of particular values in voluntary and community organisations (Blake et al, 2006; Jochum and Pratten, 2008). Yet empirical evidence for distinctive characteristics and practices is rather threadbare. We are left with the possibility that claims for distinctiveness ought to be analysed as much for their strategic intent as their empirical basis, such that being distinctive implies being 'better' and/or worthy of attention (Macmillan, 2013). Notably, this question has typically been framed in terms of how the voluntary sector is different, not whether it is. There has been an underlying assumption of distinctiveness, and within this, implicitly, an assumption of value. Arguably these assumptions have driven the push for resources and policy attention on the voluntary sector, or parts of it, by many intermediary, representative and umbrella bodies (see Third Sector Research Centre, 2014).

An unintended by-product of academic specialisation has arguably been the loosening and fraying of connections with core intellectual disciplines. In voluntary sector studies, the institutionalisation of a specialist field, especially when combined with an underlying 
assumption or argument that the voluntary sector is somehow different and merits special attention, may have had the effect of marginalising its questions and concerns within the wider field of Social Policy. This matters in so far as it filters through into Social Policy writing and research. We end up with the possibility that Social Policy as a discipline continues its overall neglect of the voluntary sector, whilst voluntary sector-focused academics inadvertently collude in the reproduction of 'separate spheres' between the state- and (quasi) market- focused world of welfare on the one hand, and the world of voluntary organisation on the other.

\section{Promising New Directions}

One of the consequences of the consolidation of voluntary sector studies as an area of knowledge building, as discussed above, is that scholars have become increasingly sensitive to the variety of forms of voluntary action ('internal diversity'); and to the complex ways in which the character of such action is intimately bound up with a range of socio-economic and political processes ('external variety'). We will consider each aspect in turn.

Before the 1990s, practitioners and scholars had already acknowledged significant ways in which organisations' size, legal status and geographical positions mattered, in terms of significance, capacities and influence, but tended not to consistently look at variation between substantive areas of work, activity, or problem solving. In other words, there had been no analogy to how markets are conventionally differentiated by 'industry', and state responsibilities by public policy field and associated specialisms of expertise. The Johns Hopkins study rectified this with a bespoke classification system designed using inductive methods, establishing the so-called 'International Classification of Nonprofit Organisations' (ICNPO) as a key entry point for understanding the anatomy of the sector (Salamon and Anheier, 1997; Kendall and Knapp, 1996).

Such a fields-based approach has provided a valuable basis for research in three ways to date. First, it has stabilised and rendered systematic aggregate economic mapping exercises, such as the data series of NCVO and the Third Sector Research Centre, through whom it has now become institutionalised (Benard et al, 2018). Second, it has also been used to compare and contrast the trajectories of voluntary sector organisation for the purpose of policy analysis. This stream of work shows how these organisations' capacities to contribute and achieve impacts as policy actors are significantly shaped by the proximate institutions they encounter within the specific policy communities they inhabit - whether it be social care, development and housing, education, or others (see Kendall, 2003; Rees and Mullins, 2016).

Third, the relevant fields have increasingly been understood in a more sociological way, bringing into focus how such policy communities and areas of activity are socially and politically constructed and contested, involving symbolic as well as more material resources and activities. There are a number of 'varieties of field theory' in play in the international literature (Barman, 2016). In the UK, the influence of Bourdieu (see Crossley, 2002) and Fligstein and McAdam (2012) are becoming important reference points (Macmillan, 2013; 
Macmillan et al, 2013). Each has helped to show how social power is manifested, and social skill expressed, in field-based situations.

With their emphases on the 'meso' level, field-level analysts have been especially concerned with how specialist (often geographically local) policy community relationships shape third sector policy roles and possibilities. A more 'externally' driven and 'macro' entry point for analysis involves keeping issues relating to sectoral identity and status at the forefront in a more overarching and cross cutting way, orienting the analysis especially to its collective interactions with the web of socio-political institutions within which its development is enmeshed. Here, social policy developments which cut across levels and fields are assumed to be cumulative and mutually reinforcing, involving political and social forces acting in concert in ways which serve to shape the sector as a whole. Implicitly, the scope for relatively autonomous dynamics within specialist fields of policy (and hence for voluntary organisations inside those fields) is depicted as contained by powerful macro level and politics and policies, and it is the environment at this level which is key. This strand of work therefore shares with the sociological version of fields theory a focus upon social and political construction, but now attention is directed towards processes which are taken to be more macro and potentially encompassing in character.

This work, which is often broadly 'new institutional' in character (Scott, 2014) has developed along three promising lines. First, in studies stressing isomorphism (cf. Powell and DiMaggio, 1991) relationships between the State and voluntary organisations are seen as symbiotic but heavily asymmetric in favour of the former, potentially involving a range of dysfunctional pressures for conformity and compliance as more policy attention is focussed on the sector. In the face of the concentration of power and resources in the hands of the State on the one hand, and social policies systematically promoting commodification across relevant policy fields on the other, these pressures are portrayed as threats to this sector's capacity to function independently and effectively on behalf of its constituents, adequately differentiated from state and market practices (Milbourne and Cushman, 2015; Milbourne and Murray, 2017) $)^{1}$.

Second and relatedly, analysts have sought to consider how macro ideologies (variously defined) and governmentalities (in the Foucauldian tradition) relate to and mould the contours of voluntary action, portraying this domain as subject to ubiquitous and intrusive modes of control, diffused at every level, changing the conditions under which the sector develops. Here both centripetal and centrifugal forces are said to be in play: centripetally, dominant ideational frameworks and institutionally embedded narratives and dispositions associated with neoliberalism, new public management and marketisation can tend to induce convergence; but centrifugally, competing variants of these approaches emerge, evolve and mutate differently, according to the character of power relations and the agendas of those involved. The net result can be unstable combinations of both incorporation and overbearing control on the one hand, but the existence of some room for

\footnotetext{
${ }^{1}$ It is worth noting that Barman (2016), drawing heavily on US literature, suggests that the study of isomorphic developments can be understood as part of the family of meso-level field theories. However, UK based applications of the approach tend to focus on macro processes that cut across and encompass fields, perhaps reflecting the extent to which British social policies are typically more centrally directed and tightly coupled than their US counterparts.
} 
continued autonomy and innovation on the other (in particular, see Carmel and Harlock, 2008; Harlock, 2014).

Third, some scholars have pointed to hybridisation as an emerging pattern associated with the increased intensity and extensity of relationships between sectors, whereby not only are identities potentially pressurised, stretched, and reconfigured in the face of isomorphic and ideological currents and counter currents, but are ultimately dissolved, reconstituted and multiplied. An emerging literature on 'hybridisation' advances this idea through highlighting social and political processes which challenge and undermine established conceptual boundaries between formal sectors (i.e. state, market, third) by systematically fusing or conflating institutions and practices which had previously been treated as relatively distinct (Pestoff and Brandsen, 2008; Billis, 2010; Henriksen et al, 2015).

\section{Conclusion}

In this chapter we have reviewed developing scholarship on the voluntary or third sector in the UK, within the context of social policy. We have argued that the voluntary sector has traditionally been relatively marginalised in social policy thinking, and overlooked in the analysis of welfare policies, institutions and outcomes. Tentatively, we have suggested a somewhat myopic frame of reference in mainstream social policy scholarship (in its longstanding focus on states, and latterly markets and quasi-markets, in welfare provision), combined with the emergence of a specialist - but sometimes balkanised - field of voluntary sector studies. But there are healthy counter currents too: we have considered a range of theoretical developments which, in various ways, attempt to offer contextually sensitive accounts of the role of the third sector in social policy, to help bridge the divide between the two.

We have used the term 'sector' throughout the discussion as a short-hand for describing a wide range of formal and informal activities, structures and relationships occurring through the auspices of organisations ostensibly beyond the state and the market. Our contention is that 'sector' thinking underpins so much, and perhaps too much, policy analysis and commentary in social policy, and there is a need for disaggregation. In pursuing our argument, we have cause to question the notion of 'sector' and suggest that it risks reifying and enclaving activities behind untested assumptions, and solidifying boundaries which are otherwise emergent, contested, and always only provisionally accomplished and fragile (Macmillan, 2013).

Speaking in 1949, William Beveridge referred to a 'perpetually moving frontier' between the state and philanthropic action (Beveridge, 1949, a theme later taken up by Finlayson, 1994). The aim was to reserve a place for voluntary action in the newly emerging state-led postwar welfare settlement. The idea of a 'moving frontier' is typically invoked in order to account for historical shifts in the evolving mixed economy of state, market, commercial and informal welfare (Lewis, 1999; Alcock, 2016). But we suggest that it is more realistic and fruitful to think of the existence and interplay of multiple moving frontiers. A multi-level analysis is required here, combining, or at least appreciating the interdependence of, macro- and meso-levels (as we have indicated in our discussion), but also adding a micro- 
level of fluid inter-personal relationships, everyday practices and identities across institutionalised but blurred and dynamic professional and 'sector' boundaries. We recognise the institutional efforts involved in creating and maintaining named, privileged and credentialised domains of activity in social policy, welfare-related services and academic scholarship. But we should make these processes, and their moving frontiers, part of the object of social policy enquiry, rather than let them channel our thinking so that we become oblivious to the full range of social policy phenomena worth exploring.

\section{References}

Alcock, P. (2010) 'A strategic unity: defining the third sector in the UK', Voluntary Sector Review, 1(1): 5-24.

Alcock, P. (2016) Why we need welfare: Collective action for the common good (Bristol, Policy Press).

Amin, A. (1996) 'Beyond associative democracy’, New Political Economy, 1(3): 309-333.

Baring Foundation (2012) Protecting independence: The voluntary sector in 2012 (London, Baring Foundation, Civil Exchange and DH Communications).

Barman, E. (2016) 'Varieties of field theory and the sociology of the non-profit sector', Sociological Compass, 10(6): 442-458.

Beresford, P. (2016) All Our Welfare: Towards participatory social policy (Bristol, Policy Press).

Beresford, P. and Croft, S. (1983) 'Welfare pluralism: the new face of Fabianism', Critical Social Policy, 3 (Issue 9): 19-39.

Benard, C., Lloyd, G., Egan, J., Dobbs, J., Hornung, L., Lawson, M., Ockenden, N. and Jochum, V. (2017) The UK Civil Society Almanac 2017 (London, NCVO).

Benard, C., Davies, J., Dobbs, J., Hornung, L., Jochum, V., Lawson, M. and McGarvey, A. (2018) The UK Civil Society Almanac 2018 (London, NCVO).

Beveridge, W. (1949) 'Voluntary Action for Social Progress', House of Lords, HL Deb 22 June 1949 , vol. 163, col.95.

Billis, D. (2001) 'Tackling Social Exclusion: The Contribution of Voluntary Organisations', in Harris, M. and Rochester, C. (eds) Voluntary Organisations and Social Policy in Britain: Perspectives on Change and Choice (Basingstoke, Palgrave Macmillan), pp.37-48.

Billis, D. (ed)(2010) Hybrid Organizations and the Third Sector: Challenges for Practice, Theory and Policy (Basingstoke, Palgrave Macmillan). 
Billis, D. and Glennerster, H. (1998) 'Human services and the voluntary sector: towards a theory of comparative advantage', Journal of Social Policy, 27(1): 79-98.

Billis, D. and Harris, M. (1996) 'Introduction: Enduring Challenges of Research and practice' in Billis, D. and Harris, M. (eds) Voluntary Agencies: Challenges of Organisation and Management (Basingstoke, Macmillan), pp.1-12.

Birch, A.H. (1984) 'Overload, Ungovernability and Delegitimation: The Theories and the British Case', British Journal of Political Science, 14(2): 135-60.

Blake, G., Robinson, D. and Smerdon, M. (2006) Living values: A report encouraging boldness in third sector organisations (London, Community Links).

Bochel, H. and Powell, M. (eds)(2016) The Coalition Government and Social Policy: Restructuring the welfare state (Bristol, Policy Press).

Brenton, M. (1985) The Voluntary Sector in British Social Services (Harlow, Longman).

Carmel, E. and Harlock, J. (2008) 'Instituting the third sector as a governable terrain: partnership, procurement and performance in the UK', Policy \& Politics, 36(2): 155-171.

Clifford, D. (2017) 'Charitable organisations, the Great Recession and the Age of Austerity: Longitudinal Evidence for England and Wales', Journal of Social Policy, 46(1): 1-30.

Clifford, D. and Mohan, J. (2016) 'The Sources of Income of English and Welsh Charities: An Organisation-Level Perspective', Voluntas, 27(1): 487-508.

Clifford, D., Geyne-Rahme, F., and Mohan, J. (2013) 'Variations between organisations and localities in government funding of third-sector activity: Evidence from the national survey of third-sector organisations in England', Urban Studies, 50(5): 959-976.

Crees, J., Davies, N., Jochum, V. and Kane, D. (2016) Navigating Change: An Analysis of Financial Trends for Small and Medium-Sized Charities (London, NCVO/Lloyds Bank Foundation for England and Wales).

Crossley, N. (2002) Making Sense of Social Movements (Buckingham, Open University Press).

Deakin, N. (1987) The Politics of Welfare (London, Methuen).

Esping-Andersen, G. (1990) The Three Worlds of Welfare Capitalism (Cambridge, Polity Press).

Esping-Andersen, G. (1999) Social Foundations of Postindustrial Economies (Oxford, Oxford University Press).

Field, J. (2017) Social Capital (London, Routledge), $3^{\text {rd }}$ edition. 
Finlayson, G. (1994) Citizen, state and social welfare in Britain, 1830-1990 (Oxford, Clarendon).

Fligstein, N. and McAdam, D. (2012) A Theory of Fields (Oxford, Oxford University Press). Gladstone, F. (1979) Voluntary Action in a Changing World (London, Bedford Square Press). Grenfell, M. (ed)(2012) Pierre Bourdieu: Key Concepts, $2^{\text {nd }}$ edition (Abingdon, Routledge). Gough, I. (1979) The Political Economy of the Welfare State (Basingstoke, Macmillan). Hadley, R. and Hatch, R. (1981) Social Welfare and the Failure of the State (London, Allen \& Unwin).

Halfpenny, P. and Reid, M. (1992) 'Research on the voluntary sector: an overview', Policy \& Politics, 30(4): 533-550.

Hall, P.A. (1999) 'Social Capital in Britain', British Journal of Political Science, 29(3): 417-461. Halpern, D. (2005) Social Capital (Cambridge, Polity Press).

Hansmann, H. (1980) 'The role of non-profit enterprise', Yale Law Journal, 89(5): 835-901.

Harlock, J. (2014) 'Diversity and ambiguity in the English third sector', in Brandsen, T., Trommel, W. and Verschuere, B. (eds) Manufacturing Civil Society: Principles, Practices and Effects (Basingstoke, Palgrave Macmillan), PAGE NOS.?

Henriksen, L.S., Smith, S.R. and Zimmer, A. (2015) 'Welfare mix and hybridity: flexible adjustments to changed environments: introduction to the special issue', Voluntas, 26(5): $1591-1600$.

Hirst, P. (1994) Associative Democracy: New Forms of Economic and Social Governance (Cambridge, Polity Press).

Jochum, V. and Pratten, B. (2008) Values into action: How organisations translate their values into practice (London, NCVO).

Johnson, N. (1987) The Welfare State in Transition: The Theory and Practice of Welfare Pluralism (Brighton, Wheatsheaf).

Johnston, G. and Percy-Smith, J. (2003) 'In search of social capital', Policy \& Politics, 31(3): 321-334.

Jordan, B. (1996) A Theory of Poverty and Social Exclusion (Cambridge, Polity Press).

Kendall, J. (2003) The Voluntary Sector: Comparative Perspectives in the UK (London, Routledge). 
Kendall, J. and Knapp, M. (1995) 'A loose and baggy monster: boundaries, definitions and typologies', in Davis Smith, J., Rochester, C. and Hedley, R. (eds) An Introduction to the Voluntary Sector (London, Routledge), pp.66-95.

Kendall, J. and Knapp, M. (1996) The voluntary sector in the UK (Manchester, Manchester University Press).

Kendall et al 2018, Journal of Social Policy paper

King, A. (1975) 'Overload: problems of governing in the 1970s', Political Studies, 23(2-3): 284-296.

Le Grand, J. and Bartlett, W. (1993)(eds) Quasi-markets and Social Policy (Basingstoke, Macmillan).

Lewis, J. (1999) 'Voluntary and Informal Welfare' in Page, R.M. and Silburn, R. (eds) British Social Welfare in the Twentieth Century (Basingstoke, Macmillan), pp. 249-270.

Lewis, J. (2005) 'New Labour's approach to the voluntary sector: independence and the meaning of partnership', Social Policy and Society, 4(2): 121-31.

Macmillan, R. (2013) “Distinction' in the third sector', Voluntary Sector Review, 4(1): 39-54.

Macmillan, R., Taylor, R., Arvidson, M., Soteri-Proctor, A. and Teasdale, S. (2013) The third sector in unsettled times: a field guide (TSRC Working Paper 109, Birmingham, Third Sector Research Centre).

Maloney, W., Smith, G. and Stoker, G. (2000) 'Social Capital and Urban Governance: Adding a More Contextualised 'Top-down' Perspective', Political Studies, 48(4): 802-820.

Milbourne, L. and Cushman, M. (2015) 'Complying, transforming or resisting the new austerity? Realigning social welfare and independent action among English voluntary sector organisations', Journal of Social Policy, 44(3): 463-485.

Milbourne, L. and Murray, U. (2017) Civil Society Organisations in Turbulent Times: A gilded web (London Trentham Books/UCL-IOE Press).

O'Connor, J. (1973) The Fiscal Crisis of the State (New York, St. Martin's Press).

Offe, C. (1984) Contradictions of the Welfare State (London, Hutchinson).

Pestoff, V. and Brandsen, T. (eds) (2008) Co-Production: The Third Sector and the Delivery of Public Services (London, Routledge).

Pinker, R.A. (1979) The Idea of Welfare (London, Heinemann). 
Powell, M. (2016) 'Citation Classics in Social Policy Journals', Social Policy \& Administration, 50(6): 648-672.

Powell, W.W. and DiMaggio, P. (eds) (1991) The New Institutionalism in Organizational Analysis (Chicago, University of Chicago Press).

Prochaska, F. (1988) The Voluntary Impulse: Philanthropy in Modern Britain (London, Faber \& Faber).

Putnam, R.D., Leonardi, R. and Nanetti, R.Y. (1993) Making democracy work: Civic traditions in modern Italy (Princeton, N.J., Princeton University Press).

Putnam, R.D. (2000) Bowling Alone: The Collapse and Revival of American Community (New York, Simon \& Schuster).

Rees, J. and Mullins, D. (eds) (2016) The Third Sector Delivering Public Services:

Developments, Innovations and Challenges (Bristol, Policy Press).

Reisman, D.A. (2001) Richard Titmuss: Welfare and Society, 2nd ed. (London, Palgrave).

Rochester, C. (2013) Rediscovering Voluntary Action: The Beat of a Different Drum (Basingstoke, Palgrave Macmillan).

Salamon, L.M. and Anheier, H.K. (1997) Defining the Nonprofit Sector: A Cross-National Analysis (Manchester, Manchester University Press).

Salamon, L.M. and Anheier, H.K. (1998) 'Social Origins of Civil Society: Explaining the Nonprofit Sector Cross-Nationally', Voluntas, 9(3): 213-48.

Salamon, L.M., Sokolowski, S.W. and Haddock, M.A. (2017) Explaining Civil Society Development: A Social Origins Approach (Baltimore, Johns Hopkins University Press)

Scott, W.R. (2014) Institutions and Organizations: Ideas, Interests and Identities, $4^{\text {th }}$ edition (London, Sage).

Smith, G. (2011) 'Putting democracy into welfare provision' in Westall, A. (ed) Revisiting Associative Democracy how to get more co-operation, co-ordination and collaboration into our economy, our democracy, our public services, and our lives (London, Lawrence and Wishart), pp.54-58.

Szreter, S. (2002) 'The state of social capital: Bringing back in power, politics and history', Theory and Society, 31(5): 573-621.

Tarling, R. (2000) 'Editorial: Statistics on the voluntary sector in the UK,' Journal of the Royal Statistical Society A, 163(3): 255-261. 
Taylor, M. (2000) 'Communities in the Lead: Power, Organisational Capacity and Social Capital', Urban Studies, 37(5-6): 1019-1035.

Third Sector Research Centre (TSRC)(2014) Understanding the UK third sector: The work of the Third Sector Research Centre 2008-2013 (Birmingham, Third Sector Research Centre).

Titmuss, R.M. (1958) Essays on 'The Welfare State' (London, Allen and Unwin), pp. 34-55.

Titmuss, R.M. (1970) The Gift Relationship: From Human Blood to Social Policy (London, Allen \& Unwin).

van Oorschot, W. and Arts, W. (2005) 'The social capital of European welfare states: the crowding out hypothesis revisited', Journal of European Social Policy, 15(1): 5-26.

Williams, F. (1989) Social Policy: A Critical Introduction (Cambridge, Polity Press).

Wolfenden, Lord (1977) The Future of Voluntary Organisations: Report of the Committee on the Future of Voluntary Organisations (London, Croom Helm). 